\title{
Genetic species identification in weatherfish and first molecular confirmation of Oriental Weatherfish Misgurnus anguillicaudatus (Cantor, 1842) in Central Europe
}

\author{
Christina C. Belle ${ }^{1, a}$, Bernhard C. Stoeckle ${ }^{1, a}$, Alexander F. Cerwenka, ${ }^{2, a}$, Ralph Kuehn ${ }^{3,4}$, \\ Melanie Mueller ${ }^{1}$, Joachim Pander ${ }^{1}$ and Juergen Geist ${ }^{1, *}$ \\ ${ }^{1}$ Aquatic Systems Biology Unit, Department of Ecology and Ecosystem Management, Technical University of Munich, \\ Muehlenweg 22, 85354 Freising, Germany \\ ${ }^{2}$ SNSB-Bavarian State Collection of Zoology (ZSM), Münchhausenstr. 21, 81247 München, Germany \\ ${ }^{3}$ Unit of Molecular Zoology, Chair of Zoology, Department of Animal Sciences, Technical University of Munich, \\ 85354 Freising, Germany \\ ${ }^{4}$ Department of Fish, Wildlife and Conservation Ecology, New Mexico State University, Box 30003, MSC 4901, \\ Las Cruces, NM 88003-8003, USA
}

\begin{abstract}
The Oriental Weatherfish is considered a globally invasive fish species. In Europe, several reported feral populations of Oriental Weatherfish display an overlapping distribution range with native weatherfish Misgurnus fossilis, a declining species of international conservation and aquatic management concern. Morphologically distinguishing the different weatherfish species can be difficult, as their coloration is highly variable, many species reveal high phenotypic plasticity, and morphological traits like coloration might be not obvious or might be degraded during field sampling and after preservation. Herein, we analysed suspicious weatherfish specimens from southern Germany, demonstrating the usefulness of molecular genetic species identifications in this genus. We present the first molecular genetic species record of Misgurnus anguillicaudatus in Central Europe, and confirm the range expansion of Oriental Weatherfish into the river Inn catchment in southern Germany. As accurate species identification is crucial both in the context of monitoring and conserving native endangered species, and in early detection and prevention of biological invasion, we suggest the standard use of genetic species identification if morphological traits are not obvious.
\end{abstract}

Keywords: Misgurnus anguillicaudatus / Misgurnus fossilis / DNA barcoding / genetic species identification / biological invasion

Résumé - Identification génétique des espèces de loche et première confirmation moléculaire de la présence de la loche baromètre Misgurnus anguillicaudatus (Cantor, 1842) en Europe centrale. La loche baromètre est considérée comme une espèce de poisson globalement invasif. En Europe, plusieurs populations sauvages signalées de la loche baromètre présentent une aire de répartition en chevauchement avec la loche d'étang indigène locale Misgurnus fossilis, une espèce en déclin, objet de conservation internationale et de gestion aquatique. La distinction morphologique des différentes espèces de loches peut être difficile, car leur coloration est très variable, de nombreuses espèces révèlent une forte plasticité phénotypique, et les traits morphologiques comme la coloration pourraient ne pas être évidents ou pourraient être dégradés lors de l'échantillonnage sur le terrain et après la conservation. Nous avons analysé les spécimens douteux du sud de l'Allemagne démontrant l'utilité des identifications génétiques moléculaires des espèces dans ce genre. Nous présentons les premières données d'identification génétique de l'espèce Misgurnus anguillicaudatus en Europe centrale et confirmons l'expansion géographique de la loche baromètre dans le bassin hydrographique de la rivière Inn dans le sud de l'Allemagne. Étant donné que l'identification précise des espèces est cruciale tant dans le contexte de la surveillance et de la conservation des espèces indigènes en voie de disparition, que dans le dépistage précoce et la prévention de l'invasion

\footnotetext{
${ }^{a}$ These authors made equal contributions to this work.

${ }^{*}$ Corresponding author: geist@wzw.tum.de
} 
biologique, nous suggérons l'utilisation standard de l'identification génétique des espèces si les traits morphologiques ne sont pas évidents.

Mots-clés : Misgurnus anguillicaudatus / Misburnus fossilis / code barres ADN / identification génétique des espèces / invasion biologique

\section{Introduction}

The Oriental Weatherfish Misgurnus anguillicaudatus (Cantor, 1842) is native to the east Asian temperate regions, including Cambodia, China, India, Japan, Korea, Laos, Taiwan, Thailand, Vietnam and the Tugur and Amur River catchments in Siberia (Kottelat and Freyhof, 2007). The species is found in still or slow-flowing rivers, lakes and ponds with muddy bottoms, and is widely associated with agricultural landscapes, especially rice fields and field ditches (Kano et al., 2010). Being at the same time an important and frequently traded ornamental fish that is also used as live bait and for human consumption, several populations of M. anguillicaudatus have established globally outside the native distribution range, e.g., in Australia (Allen, 1984), Europe (Franch et al., 2008; van Kessel et al., 2013), North America (Simon et al., 2006), South America (Abilhoa et al., 2013) and several Asian countries (e.g., Juliano et al., 1989; Sal'nikov, 1998). In Central Europe, the first record of M. anguillicaudatus was reported in 2005 solely based on morphological species identification (Freyhof and Korte, 2005).

In contrast to the globally expanding Oriental Weatherfish, Misgurnus fossilis (Linnaeus, 1758) is a species of international conservation concern (Council of the European Union, 1992, listed in Annex II of the European Habitat Directive) facing rapid population declines across its European range (Hartvich et al., 2010; Freyhof, 2013). Its original distribution range covers Central and Eastern Europe from Northern France to the River Volga in the east, including the entire Danube River basin (Lelek, 1987; Banarescu, 1990). Due to physical removal, habitat destruction, predation and competition, i.e., with introduced species, the former metapopulation is currently strongly reduced and fragmented, only covering a small percentage of the original distribution (Meyer and Hinrichs, 2000). As evident from the example of Switzerland, population declines and local extinctions of $M$. fossilis may often have been disguised by the simultaneous introduction and establishment of phenotypically highly similar exotic weatherfish species that may have been misidentified during monitoring (Freyhof, 2013).

Morphologically distinguishing the different species of Misgurnus can be difficult, as their coloration is highly variable and several species reveal high phenotypic plasticity. In this context, species form morphologically indistinguishable cryptic species complexes that can comprise different genetic lineages (Nichols, 1943; Kottelat, 2012). Moreover, genetic data confirms that several specimens have been misidentified based on their phenotype (Kottelat, 2012). By eye, $M$. anguillicaudatus and $M$. fossilis can solely be separated by the pigmentation of the dorsal part of the caudal base (Kottelat and Freyhof, 2007). An unambiguous identification of $M$. anguillicaudatus based on the presence of a conspicuous black dot on the dorsal part of the caudal base is difficult as this character is not always detectable (J. Knott, pers. comm.). Species identification is further complicated by the occurrence of a third, non-native species, Paramisgurnus dabryanus (Dabry de Thiersant, 1872), formerly described as Misgurnus mizolepis (Günther, 1888), which was also introduced to Europe (Riffel et al., 1994). Since P. dabryanus has no distinct morphological features, the phenotypic differentiation of Misgurnus sp. and P. dabryanus is even more complex.

Accurate species identification is crucial both in the context of monitoring and conserving native endangered species, as well as in early detection and prevention of the spread of non-native taxa. This is especially crucial if similar looking endangered native species and introduced species have overlapping distribution ranges as evident in the case of weatherfish species in Europe. Molecular genetic tools are increasingly considered a reliable and unambiguous alternative to classical methods of species identification (Collins et al., 2012). DNA-based molecular species identification keys have previously been successfully established in other taxonomic groups such as freshwater mussels (Zieritz et al., 2012; Beggel et al., 2015) that also face challenges of cryptic species and thus phenotypic misidentification.

In this study, we provide genetic relationships of weatherfish species based on cytochrome oxidase subunit I (COI) and analysed morphologically suspicious weatherfish from southern Germany using mitochondrial DNA barcoding, providing the first genetically confirmed record of feral $M$. anguillicaudatus in Central Europe.

\section{Materials and methods}

During intense field samplings in southern German rivers and streams from 2013 to 2015, three Misgurnus individuals (total length $6.8,8.4$, and $12.7 \mathrm{~cm}$ ) were unintentionally caught at an oxbow of the upper River Inn, close to the city of Rosenheim $\left(47^{\circ} 52^{\prime} 28.3^{\prime \prime} \mathrm{N}, 12^{\circ} 08^{\prime} 17.3^{\prime \prime} \mathrm{E}\right.$, Bavaria, Germany), in August 2015. The specimens were detected within macroinvertebrate samples that were preserved in 50\% ethanol for 6 months. Specimens and tissue vouchers were deposited at the ichthyology collection of the Bavarian State Collection Munich (ZSM).

DNA-extraction followed the phenol-chloroform protocol according to Sambrook et al. (1989). Amplification of the mitochondrial COI-5P gene was performed using the fish barcoding protocol with the M13 tailed primer cocktail C_FishF1t1 and C_FishR1t1 (Ivanova et al., 2007). The $7 \overline{30}$ bp PCR products were cleaned (NucleoSpin Gel and PCR clean-up kit, Macherey \& Nagel) and sequenced (Eurofins $\mathrm{GmbH}$, Munich).

The obtained sequences were submitted to GenBank (accession numbers KX865082-KX865084). For species identification, the sequences were included in a query search 


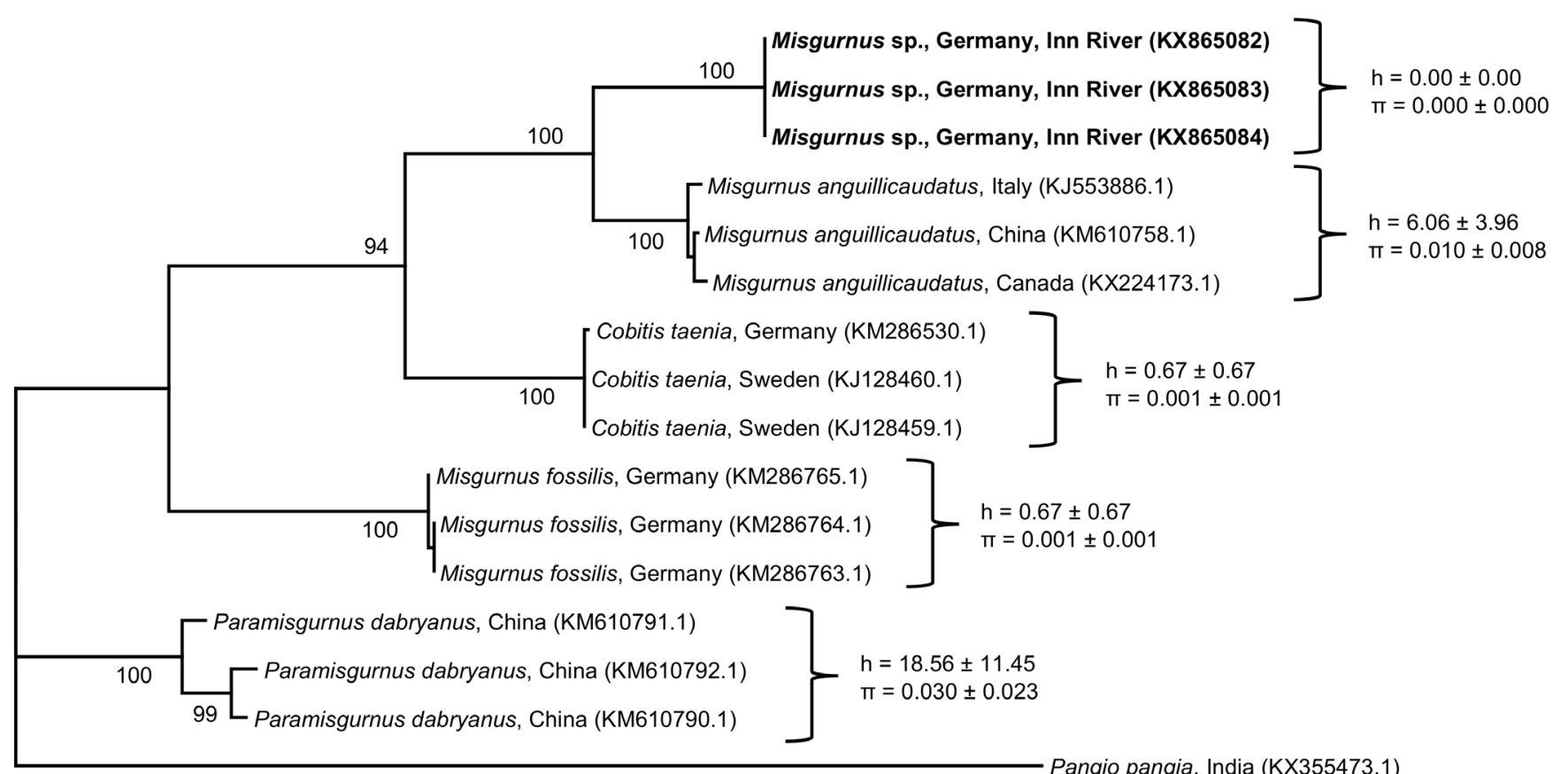

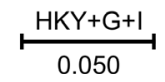

Fig. 1. Maximum likelihood (ML) estimates of phylogenetic relationships of Misgurnus sp., P. dabryanus and Cobitis taenia COI sequences (622 bp). Nodes are labeled with the highest bootstrap support by ML (1000 replications). In bold: Sequences of the identified and sequenced specimen from the oxbow at River Inn, southern Germany. All branches had bootstrap support above $60 \%$. The scale bar shows the best fit model chosen based on the Bayesian information criterion approach (Hasegawa-Kishino-Yano model with discrete Gamma distribution, HKY+G+I, above), and substitutions/site (below). In brackets, the current GenBank accession numbers of the published sequences used for this analysis. Values beside curly brackets indicate nucleotide $(\pi)$ haplotype $(h)$ and diversity.

using GenBank's BLASTN in September 2016. For the phylogenetic analysis and species assignment, sequences were aligned with published Misgurnus, P. dabryanus, Cobitis taenia and Pangio pangia (as outgroup) COI-5P sequences from Chen et al. (2015), Geiger et al. (2014) and Knebelsberger et al. (2015) sourced in, barcode of life, data system and GenBank. Maximum Likelihood method implemented in MEGA7 (Kumar et al., 2016) was used to determine the best substitution model. A phylogenetic tree of all sequences using the best-fit model $(\mathrm{HKY}+\mathrm{G}+\mathrm{I})$ and the maximum intra- and minimum interspecific uncorrected $p$ distances to estimate the "barcoding gap" between the species were computed with the same software. The diversity within species was estimated with ARLEQUIN 3.5 (Excoffier and Lischer, 2010).

\section{Results}

All three individuals retrieved maximum similarity of the 648 bp COI-5P sequence with database entries of the species M. anguillicaudatus (99-100\%). Similarities with other species of weatherfish were much lower, with $84 \%$ for $M$. fossilis and $85 \%$ for $P$. dabryanus. Analogously, the phylogenetic clustering of the trimmed barcodes clearly suggests an assignment of the specimens to M. anguillicaudatus sensu lato (Fig. 1).
The minimum genetic distance between COI sequences of $M$. anguillicaudatus and $M$. fossilis and $P$. dabryanus was $14.6 \%$ and $15.6 \%$, respectively. $M$. fossilis and P. dabryanus separate by a minimum of $15.1 \%$. The maximum intraspecific uncorrected $p$-distance in $M$. anguillicaudatus was $5.7 \%$, for M. fossilis $0.2 \%$, and for P. dabryanus $1.9 \%$.

\section{Discussion}

This study provides the first molecular record of Oriental Weatherfish, M. anguillicaudatus, in Central Europe. It also confirms the usefulness of genetic species identification in phenotypically ambiguous species of weatherfish.

Earlier records of $M$. anguillicaudatus in Central Europe were based on morphological characteristics but were to date and to the best of our knowledge not confirmed using molecular species identification. This is crucial since $M$. anguillicaudatus reveals great morphological similarity to native $M$. fossilis and non-native $P$. dabryanus, making a traditional species identification difficult.

The detection of $M$. anguillicaudatus in the Inn River catchment was unexpected since it is physically isolated and more than $300 \mathrm{~km}$ aerial distance apart from the sites where $M$. anguillicaudatus was first reported by Freyhof and Korte (2005) based on phenotypic characters. Since the species is not consumed in Europe, and since the use of live bait is not 
permitted by law, a release of specimens in the context of ornamental trade, or the unintentional introduction of the wrong species in the context of a conservation-related restocking programme currently appear the two most likely options, yet both lack further evidence.

From a conservation perspective, the accurate identification of the different weatherfish species during biomonitoring is essential for several reasons. First, monitoring and population trend analysis in both native and non-native species of weatherfish form an essential basis for their management, yet must rely on accurate species assignments. Second, conservation efforts and supportive breeding for native $M$. fossilis must ensure that the correct species is targeted. Third, avoiding the establishment and further spread of non-native weatherfish species depends on their early detection since mitigation strategies often only succeed when introduced populations are still small and only occur in spatially restricted areas.

Several records of ambiguous individuals in southern Germany (anecdotal information and own unpublished data) indicate a broader distribution of non-native weatherfish species than officially documented. This is in line with Freyhof (2013) who suggests that undiscovered feral populations likely occur in other parts of Europe, stressing the need for a more systematic screening of populations. Because of the high phenotypic variability within the genus Misgurnus and Paramisgurnus, and their increasingly overlapping distribution ranges, we suggest the standard use of genetic identification tools as used in this study.

In conclusion, unambiguous species identification is an ultimate prerequisite in appropriate conservation management. As our example illustrates, it is crucial to accurately identify invasive species, especially if they closely resemble endangered native species, and for elucidating cryptic species complexes. Furthermore, molecular techniques provide a powerful tool if morphological traits are not obvious during field sampling or degraded during preservation.

Acknowledgements. The study was conceived by C.C.B., B.C.S., and J.G. Field sampling was coordinated by J.P. and M. M. The molecular genetic work and phylogenetic analysis was led by C.C.B., B.C.S. and R.K. Morphometric analyses, voucher registration and deposition was managed by A.F.C. The manuscript was primarily written by C.C.B., B.C.S., A.F. C. and J.G. with continuous input by all co-authors. We are grateful to Dr. Bernhard Gum (Fischereifachberatung Oberbayern) for bringing to our attention the possible presence of exotic weatherfish in the Inn river catchment. We also thank Christine Seidel for technical assistance with genetic analyses, and Carolin Schaffer for her help with field sampling. Field sampling was partially funded in the framework of the Inn project by Verbund Innkraftwerke $\mathrm{GmbH}$.

\section{References}

Abilhoa V, Bornatowski H, Vitule JRS. 2013. Occurrence of the alien invasive loach Misgurnus anguillicaudatus in the Iguaçu River basin in southern Brazil: a note of concern. J Appl Ichthyol 29: 257-259.

Allen S. 1984. Occurrence of juvenile weatherfish Misgurnus anguillicaudatus (Pisces: Cobitidae) in the Yarra River. Victorian Nat 101: 240-242.
Banarescu P. 1990. Zoogeography of fresh waters. General distribution and dispersal of freshwater animals, Vol. I. Wiesbaden: Aula-Verlag, 511 p.

Beggel S, Cerwenka AF, Brandner J, Geist J. 2015. Shell morphological versus genetic identification of quagga mussel (Dreissena bugensis) and zebra mussel (Dreissena polymorpha). Aquat Invasions 10: 93-99.

Chen W, Ma X, Shen Y, Mao Y, He S. 2015. The fish diversity in the upper reaches of the Salween River, Nujiang River, revealed by DNA barcoding. Sci Rep 5: 17437.

Collins RA, Armstrong KF, Meier R, et al. 2012. Barcoding and border biosecurity: identifying cyprinid fishes in the aquarium trade. PLoS ONE 7: e28381, 1-13.

Council of the European Union. 1992. Directive 92/43/ EEC of the European Parliament and the Council of 21st May 1992 on the conservation of natural habitats and of wild fauna and flora. Official Journal of the European Communities L206, 750 p.

Excoffier L, Lischer HEL. 2010. Arlequin suite ver 3.5: A new series of programs to perform population genetics analyses under Linux and Windows. Mol Ecol Resour 10: 564-567.

Franch N, Clavero M, Garrido M, et al. 2008. On the establishment and range expansion of oriental weatherfish (Misgurnus anguillicaudatus) in NE Iberian Peninsula. Biol Invasions 10: 1327-1331.

Freyhof J. 2013. Misgurnus fossilis, The IUCN Red List of Threatened Species 2013, e.T40698A10351495, accessed on: 2016/16/08.

Freyhof J, Korte E. 2005. The first record of Misgurnus anguillicaudatus in Germany. J Fish Biol 66: 568-571.

Geiger MF, Herder F, Monaghan MT, et al. 2014. Spatial heterogeneity in the Mediterranean Biodiversity Hotspot affects barcoding accuracy of its freshwater fishes. Mol Ecol Resour 14: $1210-1221$.

Hartvich P, Lusk S, Rutkayová J. 2010. Threatened fishes of the world: Misgurnus fossilis (Linnaeus, 1758) (Cobitidae). Environ Biol Fishes 87: 39-40.

Ivanova NV, Zemlak TS, Hanner RH, Hebert PDN. 2007. Universal primer cocktails for fish DNA barcoding. Mol Ecol Notes 7: $544-548$

Juliano RO, Guerrero R III, Ronquillo I. 1989. The introduction of exotic aquatic species in the Philippines. In: de Silva SS, ed. Exotic aquatic organisms in Asia. Manila, Philippines: Asian Fisheries Society, pp. 83-98.

Kano Y, Kawaguchi Y, Yamashita T, Shimatani Y. 2010. Distribution of the oriental weatherloach (Misgurnus anguillicaudatus) on paddy fields and its implications for conservation in Sado Island, Japan. Ichthyol Res 57: 180-188.

Knebelsberger T, Dunz AR, Neumann D, Geiger MF. 2015. Molecular diversity of Germany's freshwater fishes and lampreys assessed by DNA barcoding. Mol Ecol Resour 15: 562-572.

Kottelat M. 2012. Conspectus cobitidum: an inventory of the loaches of the world (Teleostei: Cypriniformes: Cobitoidei). Raffles Bull Zool Suppl 26: 1-199.

Kottelat M, Freyhof J. 2007. Handbook of European freshwater fishes. Cornol: Publications Kottelat, 646 p.

Kumar S, Stecher G, Tamura K. 2016. MEGA7: molecular evolutionary genetics analysis version 7.0 for bigger data sets. Mol Biol Evol 33: 1870-1874.

Lelek A. 1987. Threatened fishes of Europe. The freshwater fishes of Europe, Vol. 9. Wiesbaden: Aula-Verlag, 343 p.

Meyer L, Hinrichs D. 2000. Microhabitat preferences and movements of the weatherfish, Misgurnus fossilis, in a drainage channel. Environ Biol Fishes 58: 297-306. 
Nichols JT. 1943. The freshwater fishes of China. Natural history of Central Asia, Vol. IX. New York, NY: The American Museum of Natural History.

Riffel M, Schenk M, Schreiber A. 1994. Electrophoretic differentiation between European loach (Misgurnus fossilis L.) and oriental weatherfish (Misgurnus mizolepis Günther), an autochtonous and a feral species of central European freshwater fish. Z Angew Zool 80: $473-483$.

Sal'nikov VB. 1998. Anthropogenic migration of fish in Turkmenistan. J Ichthyol 38: 591-602.

Sambrook J, Fritsch EF, Maniatis T. 1989. Molecular cloning: a laboratory manual. Cold Spring Harbor: Cold Spring Harbor Laboratory Press, 1626 p.
Simon TP, Bright G, Veraldi F, Smith JR, Stahl JR. 2006. New records for the alien oriental weatherfish, Misgurnus anguillicaudatus, in the Lake Michigan basin, Indiana (Cypriniformes: Cobitidae). Proc Indiana Acad Sci 115: 32-36.

van Kessel N, Dorenbosch M, Crombaghs B, Niemeijer B, Binnendijk E. 2013. First record of Asian weather loach Misgurnus anguillicaudatus (Cantor, 1842) in the River Meuse basin. Bioinvasions Rec 2: 167-171.

Zieritz A, Gum B, Kuehn R, Geist J. 2012. Identifying freshwater mussels (Unionoida) and parasitic glochidia larvae from host fish gills: a molecular key to the North and Central European species. Ecol Evol 2: 740-750.

Cite this article as: Belle CC, Stoeckle BC, Cerwenka AF, Kuehn R, Mueller M, Pander J, Geist J. 2017. Genetic species identification in weatherfish and first molecular confirmation of Oriental Weatherfish Misgurnus anguillicaudatus (Cantor, 1842) in Central Europe. Knowl. Manag. Aquat. Ecosyst., 418, 31. 